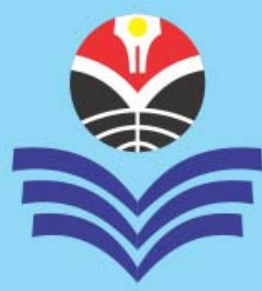

Published every March and September

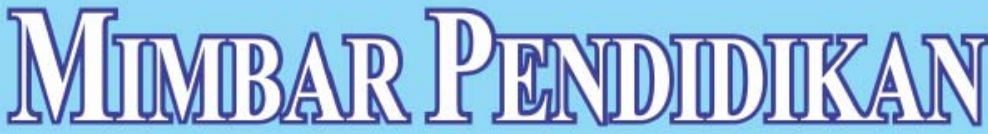

Jurnal Indonesia untuk Kajian Pendidikan

RENE R. BELECINA \& JOSE M. OCAMPO, JR.

\title{
Mathematical Curiosity, Epistemological Beliefs, and Mathematics Performance of Freshman Preservice Teachers
}

\begin{abstract}
There are many factors that influence academic performance of students. Some of these are related to personological, sociological, and psychological factors. In recent years, academic achievement and performance have been linked to several psychological factors. Two of these psychological factors that may have direct impact or influence on academic performance are curiosity and epistemological beliefs. The study described the level of mathematical curiosity and epistemological beliefs of first year preservice teachers. Mathematical curiosity includes epistemic curiosity, perceptual curiosity, exploration, and absorption. Epistemological beliefs include certainty of knowledge, source of knowledge, structure of knowledge, control of knowledge acquisition (personal), control of knowledge acquisition (general), and speed of knowledge acquisition. Three research instruments were utilized in this study, namely: Curiosity Inventory, Epistemological Beliefs Inventory, and Mathematics Performance Test. The participants of the study were 167 freshman preservice teachers. Data revealed that mathematics curiosity and epistemological beliefs are significantly related to mathematics performance and they also significantly influence mathematics performance.
\end{abstract}

KEY WORD: Psychological factor, epistemological beliefs, mathematics curiosity, preservice teachers, and mathematics performance.

ABSTRAKSI: “Keingintahuan Matematis, Keyakinan Epistemologis, dan Kinerja Matematika Mahasiswa Calon Guru”. Ada banyak faktor yang mempengaruhi prestasi akademik mahasiswa. Beberapa hal ini terkait dengan faktor personalogis, sosiologis, dan psikologis. Dalam beberapa tahun terakhir, prestasi dan kinerja akademik telah dikaitkan dengan beberapa faktor psikologis. Dua dari faktor-faktor psikologis yang mungkin memiliki dampak langsung atau pengaruh terhadap kinerja akademis adalah rasa ingin tahu dan keyakinan epistemologis. Studi ini menggambarkan tingkat rasa ingin tahu matematika dan keyakinan epistemologis mahasiswa guru dalam pra-jabatan tahun pertama. Keingintahuan matematika termasuk rasa ingin tahu secara epistemik, persepsi rasa ingin tahu, eksplorasi, dan penyerapan. Keyakinan epistemologis termasuk kepastian pengetahuan, sumber pengetahuan, struktur pengetahuan, pengendalian akuisisi pengetahuan (personal), pengendalian akuisisi pengetahuan (umum), dan kecepatan akuisisi pengetahuan. Tiga instrumen penelitian yang digunakan dalam penelitian ini, yaitu: Inventarisasi Keingintahuan, Inventarisasi Keyakinan Epistemologis, dan Uji Kinerja Matematika. Para peserta penelitian adalah 167 mahasiswa calon guru. Data mengungkapkan bahwa rasa ingin tahu matematika dan keyakinan epistemologis secara signifikan terkait dengan kinerja matematika dan keduanya juga secara signifikan mempengaruhi kinerja matematika.

KATA KUNCI: Faktor psikologis, keyakinan epistemologis, rasa ingin tahu matematika, mahasiswa calon guru, dan kinerja matematika.

About the Authors: Rene R. Belecina, Ph.D. is a Full Professor at the College of Graduate Studies and Teacher Education Research PNU (Philippine Normal University). Jose M. Ocampo, Jr., Ph.D. is a Full Professor at the Faculty of Education Sciences PNU (Philippine Normal University). Corresponding authors are: rrbelecina@yahoo.com and juno 6970@yahoo.com

How to cite this article? Belecina, Rene R. \& Jose M. Ocampo, Jr. (2016). "Mathematical Curiosity, Epistemological Beliefs, and Mathematics Performance of Freshman Preservice Teachers" in MIMBAR PENDIDIKAN: Jurnal Indonesia untuk Kajian Pendidikan, Vol.1(1) Maret, pp.123-136. Bandung, Indonesia: UPI Press.

Chronicle of the article: Accepted (December 13, 2015); Revised (January 29, 2016); and Published (March 11, 2016). 
RENE R. BELECINA \& JOSE M. OCAMPO, JR.,

Mathematical Curiosity, Epistemological Beliefs, and Mathematics Performance

\section{INTRODUCTION}

There are many factors that influence academic performance of students. Some of these are related to personological, sociological, and psychological factors. In recent years, academic achievement and performance have been linked to several psychological factors. Two of these psychological factors that may have direct impact or influence to academic performance are curiosity and epistemological beliefs.

Several researches have attempted to relate curiosity to various measures of academic achievement, learning performance, and understanding (Berlyne, 1960a, 1960b, and 1966; and Keller, 1999). W.H. Maw \& E.W. Maw (1972)'s findings, as cited also by H. Unal (2005), open up another dimension of the role of curiosity on mathematics, since high curious students can comprehend more than low curious students, and comprehending the problems has effects on success in problem solving (Maw \& Maw, 1972; and Unal, 2005). However, there is no empirical study to say that high curious students are better problem solvers than low curious students in mathematics.

In recent years, psychologists have become interested in whether people other than philosophers have ideas about what knowledge is and how knowledge is justified. In other words, psychologists have wondered if people have beliefs about epistemological questions (called epistemological beliefs or personal epistemological beliefs), and whether these beliefs affect in any way their learning or reasoning.

A large research effort has been devoted to investigating correlations between epistemological beliefs and performance on learning and reasoning tasks. A few typical findings include the following. Firstly, students who believe that knowledge is certain write essays that reach unqualified conclusions, even when there is evidence supporting different viewpoints, as well (Schommer, 1990). Secondly, students who believe that knowledge consists of ideas that are interconnected (rather than a disconnected series of facts) are better able to understand texts that present alternative positions on controversial ideas (Kardash \& Scholes, 1996). Thirdly, students with more sophisticated epistemological beliefs were better able to learn from an inquirybased learning environment (Windschitl \& Andre, 1998).

These findings should not be interpreted as showing that there are always strong relationships between measure of epistemological beliefs and measure of learning and reasoning. Some have found little relationship, for example, between reasoning and beliefs about the nature of science, and students who exhibit strong progress in reasoning better may show no gains at all in epistemological beliefs (Sandoval \& Morrison, 2003). In addition, correlations between epistemological beliefs and measures of learning and reasoning are often relatively low.

In recent years, concerns of mathematics education focus on the performance of pre-service teachers most specially on content rather than on pedagogy. Researches in mathematics education focus on the investigation of factors that affect mathematics performance of pre-service teachers ( $c f$ Hackett \& Betz, 1989; Hyde, Fennema \& Lamon, 1990; Cooper \& Robinson, 1991; and Isiksal, 2005).

This study was an attempt to describe the relationship of mathematical curiosity and epistemological beliefs to mathematics performance of pre-service teachers.

\section{CONCEPTUAL FRAMEWORK AND STATEMENT OF THE PROBLEM}

B. Renner (2006) reported that curiosity has been conceptualized as the desire for new information and knowledge. Thus, given the importance and relevance of curiosity to learning, researchers developed various measures to assess individual differences in curiosity. D.E. Berlyne (1960) recognized 


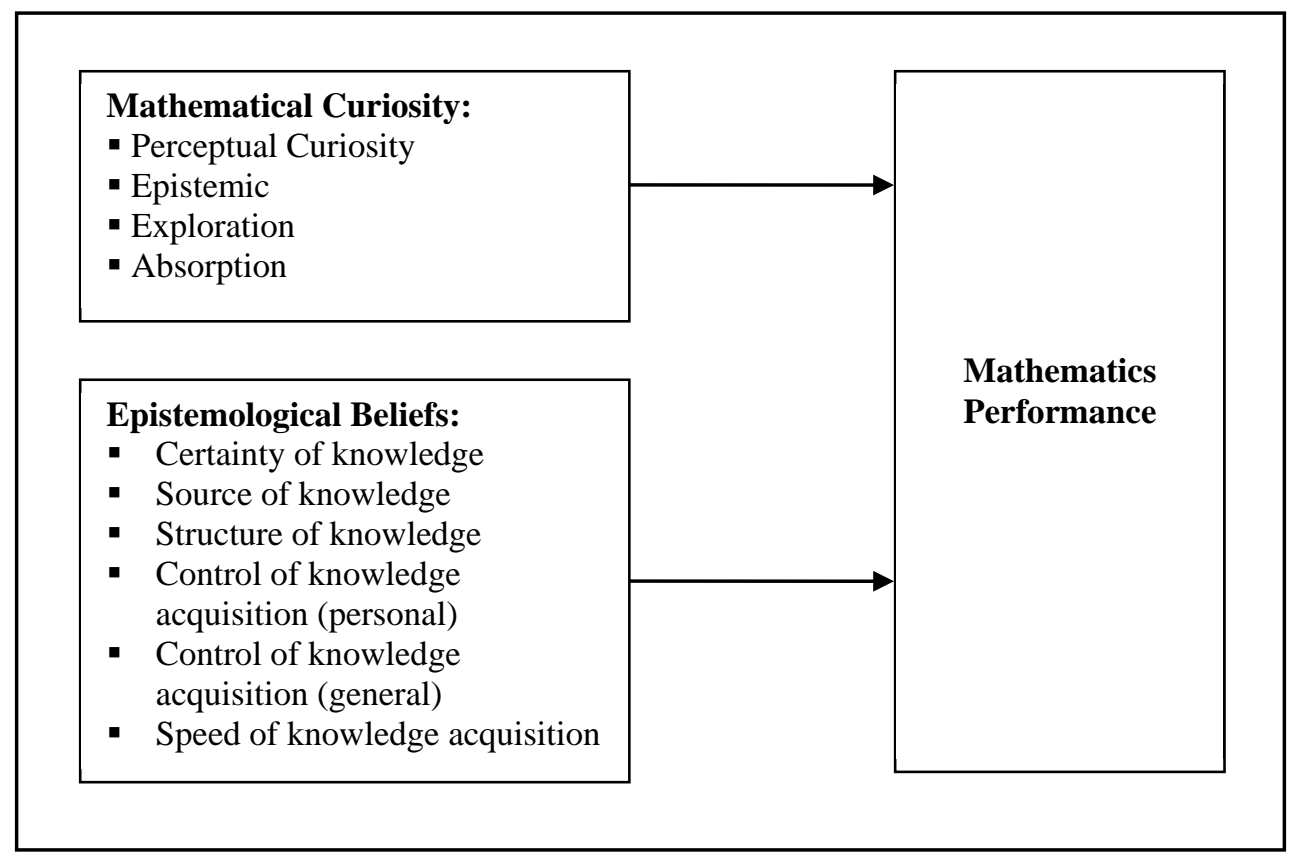

Figure 1:

Conceptual Paradigm

that the concept had become fragmented and proposed a categorization of different types of curiosity. He located curiosity on two dimensions: one extending between perceptual and epistemic curiosity. Perceptual curiosity refers to a drive which is aroused by novel stimuli and reduced by continued exposure to these stimuli (Berlyne, 1960). On the other hand, epistemic curiosity refers to desire for knowledge and applied mainly to humans (Loewenstein, 1994).

Over the past two decades, the study of students' mathematics-related beliefs has gradually received more and more attention in the field of mathematics education research. Positive beliefs about mathematics and mathematics learning are considered as a major component of competence in mathematics (De Corte, 2008).

M. Schommer (1990) proposed five dimensions of epistemological beliefs. These are certainty of knowledge, structure of knowledge, source of knowledge, control of knowledge acquisition, and speed of knowledge acquisition ( $c f$ Schommer,
1990; and Bonjour, 2002). The conceptual paradigm of this study is shown in figure 1. The paradigm shows the dimensions of mathematical curiosity and epistemological beliefs and their influence to mathematics performance.

The study aimed to describe the mathematical curiosity, epistemological beliefs, and mathematics performance of freshman pre-service teachers. It also determined the relationship of the mathematical curiosity and epistemological beliefs to mathematics performance.

Specifically, it sought answers to the following questions. Firstly, what is level of mathematics curiosity of pre-service teachers in terms of the following: epistemic curiosity, perceptual curiosity, exploration, and absorption?

Secondly, what is the level of epistemological beliefs of pre-service teachers in terms of the following: certainty of knowledge, source of knowledge, structure of knowledge, control of knowledge acquisition (personal), control of knowledge 
acquisition (general), and speed of knowledge acquisition?

Thirdly, is there a significant relationship between mathematics performance and the following variables: mathematical curiosity and epistemological beliefs?

Fourthly, which of the following variables significantly influence mathematics performance: mathematical curiosity and epistemological beliefs?

\section{METHODS}

Research Design. The study employed the descriptive research design. According to J.W. Best \& J. Kahn (1989), descriptive research seeks to find answers to questions through the analysis of variable relationships. The variables are non-manipulable, because the events and conditions have already occurred. Thus, the researcher merely selects the relevant variables for an analysis of their relationships (Best \& Kahn, 1989).

The descriptive research design is the most appropriate design in this study, because it is endeavour to describe the mathematical curiosity and epistemological beliefs of freshman pre-service teachers. Moreover, it also attempted to find the relationships of these variables to their mathematics performance.

Participants of the Study. The participants of the study were 167 freshman pre-service teachers from four randomly chosen sections of PNU (Philippine Normal University) during the School Year 2013-2014. Table 1 shows the distribution of the students according to sections.

Research Instrument. The following research instruments were used in this study. Firstly, Curiosity Inventory. This instrument was used to measure students' feelings about mathematical stimuli that activate cognitive processes (epistemic curiosity); sensory mathematical stimuli (perceptual curiosity); appetitive strivings for novelty (exploration); and full engagement in specific activities (absorption).
It also measures students' tendency to seek out opportunities for acquiring facts, knowledge, and ideas in mathematics. This instrument has four dimensions with a total of 30 items. Table 2 shows the dimensions of this instrument and the corresponding number of items.

This instrument was adapted from Epistemic Curiosity Inventory by J.A. Litman (2000) and J.A. Litman \& C.D. Spielberger (2003); Perceptual Curiosity Inventory by R.P. Collins, J.A. Litman \& C.D. Spielberger (2004); and Curiosity and Exploration Inventories I and II by T.B. Kashdan (2004) and T.B. Kashdan \& P.J. Silvia (2009). The reliability coefficient of this instrument is 0.94 .

Each item in the instrument is answerable using a 5-point scale, as showen in table 3.

Scores for the individual subscales are computed by taking the mean of the items within that subscale. See table 4.

\section{Secondly, Epistemological Beliefs}

Inventory. This instrument was used to measure math-related epistemological beliefs on five dimensions proposed by M. Schommer (1990) in her model. These dimensions are certainty of knowledge, source of knowledge, structure of knowledge, control of knowledge acquisition (personal and general), and speed of knowledge acquisition (Schommer, 1990). See table 5.

Students answered each item in the instrument on a 5-point rating scale. See table 6.

The overall score for a given dimension represents the positive wording of all items within that dimension and so higher scores indicate higher levels of epistemology in the dimension being measured. See table 7 .

\section{Thirdly, Mathematics Performance}

Test. This instrument was used to measure students' performance in mathematics. It consists of 50 multiple-choice items measuring their knowledge, mostly in problem solving. The items included in this test were based from the second general mathematics course for pre-service teachers. 
Table 1:

Distribution of the Respondents According to Section

\begin{tabular}{ccc}
\hline Section & Number of Students & Percent(\%) \\
\hline A & 42 & 25 \\
B & 45 & 27 \\
C & 40 & 24 \\
D & 40 & 24 \\
\hline Total & $\mathbf{1 6 7}$ & $\mathbf{1 0 0}$ \\
\hline
\end{tabular}

Table 2:

Distribution of Items in the Curiosity Inventory According to Dimension

\begin{tabular}{lc}
\hline \multicolumn{1}{c}{ Dimensions } & Number of Items \\
\hline Epistemic Curiosity & 6 \\
Perceptual Curiosity & 5 \\
Exploration & 10 \\
Absorption & 9 \\
\hline Total & $\mathbf{3 0}$ \\
\hline
\end{tabular}

Table 3:

Answerable Using a 5-Point Scale

\begin{tabular}{cc}
\hline Response & Verbal Description \\
\hline 5 & Always \\
4 & Often \\
3 & Sometimes \\
2 & Rarely \\
1 & Never \\
\hline
\end{tabular}

Table 4:

Mean and Verbal Description

\begin{tabular}{cc}
\hline Mean & Verbal Description \\
\hline $4.51-5.00$ & Very high \\
$3.51-4.50$ & High \\
$2.51-3.50$ & Moderately high \\
$1.51-2.50$ & Low \\
$1.00-1.50$ & Very low \\
\hline
\end{tabular}

Table 5:

Distribution of Items in the Curiosity Inventory According to Dimension

\begin{tabular}{lc}
\multicolumn{1}{c}{ Dimensions } & Number of Items \\
\hline Certainty of Knowledge & 10 \\
Source of Knowledge & 10 \\
Structure of Knowledge & 10 \\
Control of Knowledge Acquisition (Personal) & 10 \\
Control of Knowledge Acquisition (General) & 10 \\
Speed of Knowledge Acquisition & 10 \\
\hline Total & $\mathbf{6 0}$ \\
\hline
\end{tabular}


Table 6:

On a 5-Point Rating Scale

\begin{tabular}{cc}
\hline Response & Verbal Description \\
\hline 5 & Strongly agree \\
4 & Agree \\
3 & Not certain \\
2 & Disagree \\
1 & Strongly disagree \\
\hline
\end{tabular}

Table 7:

Mean and Verbal Description

\begin{tabular}{cc}
\hline Mean & Verbal Description \\
\hline $4.51-5.00$ & Very high \\
$3.51-4.50$ & High \\
$2.51-3.50$ & Moderately high \\
$1.51-2.50$ & Low \\
$1.00-1.50$ & Very low \\
\hline
\end{tabular}

Table 8:

Students’ Level of Mathematical Curiosity on Exploration

\begin{tabular}{lccc}
\hline \multicolumn{1}{c}{ Indicators } & Mean & $\begin{array}{c}\text { Standard } \\
\text { Deviation }\end{array}$ & $\begin{array}{c}\text { Verbal } \\
\text { Interpretation }\end{array}$ \\
\hline $\begin{array}{l}\text { 1. I would describe myself as someone who actively seeks as } \\
\text { much information as I can in a new situation. }\end{array}$ & 4.16 & 0.87 & High \\
$\begin{array}{l}\text { 2. I find myself looking for new opportunities to grow as a } \\
\text { person (e.g. information, people, and resources). }\end{array}$ & 4.45 & 0.78 & High \\
$\begin{array}{l}\text { 3. I actively seek as much information as I can in new situations. } \\
\text { 4. I am at my best when doing something that is complex or } \\
\text { challenging. }\end{array}$ & 4.12 & 0.65 & High \\
$\begin{array}{l}\text { 5. I am always looking for experiences that challenge how I } \\
\text { think about myself and the world. }\end{array}$ & 4.12 & 0.82 & High \\
$\begin{array}{l}\text { 6. I frequently seek out opportunities to challenge myself and } \\
\text { grow as a person. }\end{array}$ & 4.18 & 0.87 & High \\
\hline \multicolumn{1}{c}{ Overall } & $\mathbf{4 . 2 1}$ & $\mathbf{0 . 8 5}$ & High \\
\hline
\end{tabular}

Data Gathering Procedure. The Curiosity Inventory was administered to the students during the first week of the second semester while the Epistemological Beliefs Inventory was administered on the second week of the semester. The Mathematics Performance Test was administered at the end of the semester.

\section{RESULTS AND DISCUSSION}

The succeeding discussion describes the results of the study. Table 8 shows the students' level of mathematical curiosity on exploration. It can be viewed from the table that the students have high level of mathematical curiosity on exploration. This means that they have high level of appetitive strivings for novelty and challenge as well as awareness and clarity of their emotions with willingness to express positive feelings openly. In addition, the six items in this dimension of curiosity indicates that the students are willing to look for new opportunities to grow as a person and they want to do complex and challenging things.

Table 9 shows the students' level of mathematical curiosity on absorption. It can be seen from the table that the students have generally high level of curiosity on 
Table 9:

Students’ Level of Mathematical Curiosity on Absorption

\begin{tabular}{|c|c|c|c|}
\hline Indicators & Mean & $\begin{array}{l}\text { Standard } \\
\text { Deviation }\end{array}$ & $\begin{array}{c}\text { Verbal } \\
\text { Interpretation }\end{array}$ \\
\hline $\begin{array}{l}\text { 1. When I am actively interested in something, it takes a } \\
\text { great deal to interrupt me. }\end{array}$ & 4.09 & 1.02 & High \\
\hline $\begin{array}{l}\text { 2. Everywhere I go, I am out looking for new things or } \\
\text { experiences. }\end{array}$ & 4.01 & 0.97 & High \\
\hline 3. I like to do things that are a little frightening. & 3.56 & 0.95 & High \\
\hline 4. I prefer jobs that are excitingly unpredictable. & 3.23 & 0.87 & Moderately high \\
\hline $\begin{array}{l}\text { 5. I am the kind of person who embraces unfamiliar people, } \\
\text { events, and places. }\end{array}$ & 3.89 & 1.10 & High \\
\hline Overall & 3.75 & 1.08 & High \\
\hline
\end{tabular}

Table 10:

Students' Level of Mathematical Curiosity on Epistemic Curiosity

\begin{tabular}{|c|c|c|c|}
\hline Indicators & Mean & $\begin{array}{l}\text { Standard } \\
\text { Deviation }\end{array}$ & $\begin{array}{c}\text { Verbal } \\
\text { Interpretation } \\
\end{array}$ \\
\hline $\begin{array}{l}\text { 1. Difficult conceptual problems can keep me awake all } \\
\text { night thinking about solutions. }\end{array}$ & 4.12 & 0.75 & High \\
\hline 2. I enjoy learning about subjects that are unfamiliar to me. & 3.65 & 0.82 & High \\
\hline $\begin{array}{l}\text { 3. I can spend hours on a single problem because I just can't } \\
\text { rest without knowing the answer. }\end{array}$ & 3.21 & 0.95 & Moderately high \\
\hline $\begin{array}{l}\text { 4. If I read something that puzzles me at first, I keep reading } \\
\text { until I understand it. }\end{array}$ & 4.24 & 1.01 & High \\
\hline $\begin{array}{l}\text { 5. It bothers me if I come across a word that I don't know, so } \\
\text { I will look up its meaning in a dictionary. }\end{array}$ & 4.08 & 0.87 & High \\
\hline $\begin{array}{l}\text { 6. I feel frustrated if I can't figure out the solution to a } \\
\text { problem, so I work even harder to solve it. }\end{array}$ & 4.13 & 0.84 & High \\
\hline $\begin{array}{l}\text { 7. I brood for a long time in an attempt to solve some } \\
\text { fundamental problem. }\end{array}$ & 3.54 & 0.92 & High \\
\hline 8. I am critical of current ideas and theories. & 3.15 & 0.82 & Moderately high \\
\hline 9. I enjoy discussing abstract concepts. & 3.78 & 0.84 & High \\
\hline $\begin{array}{l}\text { 10. If I am given an incomplete puzzle, I like to try to find the } \\
\text { final solution. }\end{array}$ & 3.89 & 0.89 & High \\
\hline Overall & 3.78 & 0.94 & High \\
\hline
\end{tabular}

absorption. This implies that they are willing to engage in specific activities as well as the ability to persist or modify pathways to important goals even when confronted with distressing thoughts and feelings.

As indicated in their responses, it will take a great deal to interrupt them when they are actively interested in something and they are willing to look for new things and opportunities wherever they go. The item which got the lowest mean is item 4. They less likely prefer jobs that are excitingly unpredictable.
Table 10 shows students' level of mathematical curiosity on epistemic curiosity. It can be seen from the table the students' desire to engage in experiences that require cognition, in which they respond to stimuli that activate cognitive processes. The table evidently shows that the students have high level of epistemic curiosity. It appears from their responses that they keep reading thing that puzzles them until they understand it and they feel frustrated if they cannot figure out the solution to a problem, so that they even work harder to solve it. 
Table 11:

Students’ Level of Mathematical Curiosity on Perceptual Curiosity

\begin{tabular}{|c|c|c|c|}
\hline Indicators & Mean & $\begin{array}{l}\text { Standard } \\
\text { Deviation }\end{array}$ & $\begin{array}{c}\text { Verbal } \\
\text { Interpretation }\end{array}$ \\
\hline $\begin{array}{l}\text { 1. When someone asks me a riddle, I am interested in } \\
\text { trying to solve it. }\end{array}$ & 4.32 & 0.88 & High \\
\hline $\begin{array}{l}\text { 2. When I am given a new kind of arithmetic problem, I } \\
\text { enjoy imagining solutions. }\end{array}$ & 4.18 & 0.82 & High \\
\hline $\begin{array}{l}\text { 3. When I see a complicated piece of machinery, I like to } \\
\text { ask someone how it works. }\end{array}$ & 3.87 & 0.75 & High \\
\hline $\begin{array}{l}\text { 4. I enjoy exploring new ideas. } \\
\text { 5. g abstract concepts. }\end{array}$ & 4.35 & 0.83 & High \\
\hline 6. I find it fascinating to learn new information. & 4.18 & 0.92 & High \\
\hline $\begin{array}{l}\text { 7. If I am given an unfamiliar task, I like trying how it gets } \\
\text { done. }\end{array}$ & 3.92 & 0.96 & High \\
\hline $\begin{array}{l}\text { 8. When I learn something new, I would like to find out } \\
\text { more about it. }\end{array}$ & 4.35 & 0.98 & High \\
\hline $\begin{array}{l}\text { 9. When I see an incomplete puzzle, I like imagining how } \\
\text { to solve it. }\end{array}$ & 4.21 & 1.01 & High \\
\hline 10. I am interested in discovering how things work. & 4.11 & 0.75 & High \\
\hline Overall & 4.17 & 0.95 & High \\
\hline
\end{tabular}

Table 12:

Student's Epistemological Beliefs on Certainty of Knowledge

\begin{tabular}{|c|c|c|c|}
\hline Indicators & Mean & $\begin{array}{l}\text { Standard } \\
\text { Deviation }\end{array}$ & $\begin{array}{c}\text { Verbal } \\
\text { Interpretation }\end{array}$ \\
\hline 1. Most of what is true in mathematics is already known. & 3.85 & 0.98 & High \\
\hline $\begin{array}{l}\text { 2. Math is really just about knowing the right formula for the } \\
\text { problem. }\end{array}$ & 3.65 & 1.27 & High \\
\hline $\begin{array}{l}\text { 3. I prefer a math teacher who shows students several } \\
\text { different ways to look at the problem. }\end{array}$ & 3.93 & 1.05 & High \\
\hline $\begin{array}{l}\text { 4. There is usually more than one way to solve a math } \\
\text { problem. }\end{array}$ & 4.01 & 1.14 & High \\
\hline 5. Mathematical theories are the product of creativity. & 3.87 & 1.25 & High \\
\hline 6. In math, the answers are always either right or wrong. & 3.84 & 1.02 & High \\
\hline 7. Creativity has no place in a math class. & 1.85 & 1.08 & High \\
\hline $\begin{array}{l}\text { 8. All mathematics professors would probably come up with } \\
\text { the same answers to questions in their field. }\end{array}$ & 3.85 & 1.12 & High \\
\hline 9. Truth is changing in mathematics. & 1.87 & 1.24 & High \\
\hline $\begin{array}{l}\text { 10. Answers to questions in mathematics change as experts } \\
\text { gather more information. }\end{array}$ & 3.65 & 1.13 & High \\
\hline Overall & 3.47 & 1.27 & High \\
\hline
\end{tabular}

Table 11 shows the students' level of mathematical curiosity on perceptual curiosity. The table 11 also clearly shows that the students have high level of perceptual curiosity. Their responses indicate their high level of curiosity to engage in experiences triggered by sensory stimuli and a drive aroused by novel stimuli and reduced by continued exposure to these stimuli. They enjoy exploring new ideas, to learn something new and know more about it. When asked a riddle, they are interested in trying to solve it.

Table 12 shows students' epistemological beliefs on certainty of knowledge. 
Table 13:

Student's Epistemological Beliefs on Structure of Knowledge

\begin{tabular}{|c|c|c|c|}
\hline Indicators & Mean & $\begin{array}{l}\text { Standard } \\
\text { Deviation }\end{array}$ & $\begin{array}{c}\text { Verbal } \\
\text { Interpretation }\end{array}$ \\
\hline $\begin{array}{l}\text { 1. It is important for me to know why something works } \\
\text { rather than memorize a formula. }\end{array}$ & 4.29 & 0.85 & High \\
\hline $\begin{array}{l}\text { 2. When learning math, I can understand the material better } \\
\text { if I relate it to the real world. }\end{array}$ & 4.33 & 0.85 & High \\
\hline $\begin{array}{l}\text { 3. When solving problems, the key is knowing the best } \\
\text { method for each type of problem. }\end{array}$ & 2.85 & 0.78 & Moderately high \\
\hline $\begin{array}{l}\text { 4. Math is mostly facts and procedures that have to be } \\
\text { memorized. }\end{array}$ & 2.62 & 0.81 & Moderately high \\
\hline $\begin{array}{l}\text { 5. I learn best when the big picture is presented before the } \\
\text { specific steps for working a problem. }\end{array}$ & 2.36 & 0.95 & Moderately high \\
\hline $\begin{array}{l}\text { 6. I find it confusing when the teacher shows more than one } \\
\text { way to work a problem. }\end{array}$ & 2.67 & 0.78 & Moderately high \\
\hline $\begin{array}{l}\text { 7. If there weren't answers in the back of the book, I would } \\
\text { have no idea whether I had worked the problem correctly } \\
\text { or not. }\end{array}$ & 4.33 & 0.88 & High \\
\hline $\begin{array}{l}\text { 8. I don't care about why something works; just show me } \\
\text { how to work the problem. }\end{array}$ & 3.69 & 0.84 & High \\
\hline $\begin{array}{l}\text { 9. Understanding how math is used in other disciplines helps } \\
\text { me to comprehend the concepts. }\end{array}$ & 4.15 & 0.96 & High \\
\hline 10. I often learn the most from my mistakes. & 4.23 & 0.74 & High \\
\hline Overall & 3.55 & 0.89 & High \\
\hline
\end{tabular}

It can be viewed from the table 12 that the students have epistemological beliefs on certainty of knowledge. They believe that there is more than one way to solve a math problem so that they prefer a math teacher who shows students several different ways to look at the problem. Generally, they believe that most of what is true in mathematics is already known.

Table 13 shows the students' epistemological beliefs on the structure of knowledge. As can be seen from the table, the students have high level of epistemological beliefs on the structure of knowledge. The items on this dimension of epistemological beliefs are views regarding mathematics as either a collection of isolated facts or a collection of interrelated concepts.

It can be viewed from the table 13 that four items got a relatively low rating. This implies that the students do not absolutely believe that mathematics is mostly facts and procedures that have to be memorized and that they find it confusing when teacher presents more than one way to solve a problem. They generally disagree that they learn best when big picture is presented before the specific steps for working a problem.

Table 14 gives the students' epistemological beliefs on source of knowledge. The items in this dimension of epistemological beliefs are views about the source of knowledge in mathematics as either from the authority, such as mathematics teachers or from the active participation where knowledge is developed through a gradual process. They generally believe that that learning mathematics depends on having an effective teacher; that they learn math best when by working practice problems; and that to solve math problems, they have to be taught the right procedures and steps.

Table 15 shows the students' epistemological beliefs on control of 
Table 14:

Student's Epistemological Beliefs on Source of Knowledge

\begin{tabular}{|c|c|c|c|}
\hline Indicators & Mean & $\begin{array}{l}\text { Standard } \\
\text { Deviation }\end{array}$ & $\begin{array}{c}\text { Verbal } \\
\text { Interpretation }\end{array}$ \\
\hline 1. Learning math depends on having an effective teacher. & 4.41 & 0.75 & High \\
\hline $\begin{array}{l}\text { 2. I learn math best when watching the teacher work } \\
\text { example problems. }\end{array}$ & 4.25 & 0.84 & High \\
\hline 3. I learn math best by working practice problems. & 4.40 & 0.81 & High \\
\hline $\begin{array}{l}\text { 4. Teaching doesn't help a teacher understand the material } \\
\text { better; it just reminds her of how much she already knows. }\end{array}$ & 3.02 & 0.83 & Moderately high \\
\hline $\begin{array}{l}\text { 5. If math teachers gave really clear lectures with plenty of } \\
\text { good example problems, I wouldn't have to practice so } \\
\text { much on my own. }\end{array}$ & 3.54 & 0.74 & High \\
\hline $\begin{array}{l}\text { 6. The quality of a math class is not determined entirely by } \\
\text { the instructor. }\end{array}$ & 2.41 & 0.88 & Low \\
\hline $\begin{array}{l}\text { 7. What I get from a math class depends mostly on the effort } \\
\text { I invest. }\end{array}$ & 2.21 & 0.75 & Low \\
\hline 8. Math is something I could learn on my own. & 2.85 & 0.72 & Low \\
\hline $\begin{array}{l}\text { 9. To solve math problems you have to be taught the right } \\
\text { procedures and steps. }\end{array}$ & 4.37 & 0.75 & High \\
\hline $\begin{array}{l}\text { 10. In mathematics you can be creative and discover things } \\
\text { on your own. }\end{array}$ & 4.24 & 0.65 & High \\
\hline Overall & 3.57 & 0.86 & High \\
\hline
\end{tabular}

knowledge acquisition (personal). The items in this dimension are views about the control of knowledge acquisition in mathematics as either innate or acquired.

It can be gleaned from the table 15 that the students' level of epistemological beliefs on the control of knowledge acquisition is high. They generally believe that learning good study skills can improve their math skills; that asking questions when they don't understand something is very important; and that they prefer mathematics when they have to work hard to find a solution to a problem.

Table 16 shows the students' epistemological beliefs on control of knowledge acquisition (general).

The items on this dimension of epistemological beliefs are views about the control of knowledge acquisition similar to the previous dimension but viewed in the general perspective. It can be seen from the table 16 that the students have high level of epistemological beliefs on this dimension.
This is just a confirmation of their level of epistemological beliefs on the previous dimension.

Table 17 shows the students' epistemological beliefs on speed of knowledge acquisition. The items in this dimension of epistemological beliefs are views about the speed of knowledge acquisition in mathematics as either that happens quickly or not at all that has a gradual process.

It can be viewed from the table 17 that the level of epistemological beliefs on speed of knowledge acquisition is moderately high. They generally believe that almost everyone can learn Algebra if they really try; that they can do better in mathematics if they are given more time to learn the concepts; and when they encounter a problem, they stick to it until they solve it.

Table 18 gives the correlation of mathematical curiosity and epistemological beliefs to mathematics performance. 
Table 15:

Student's Epistemological Beliefs on Control of Knowledge Acquisition-Personal

\begin{tabular}{|c|c|c|c|}
\hline Indicators & Mean & $\begin{array}{l}\text { Standard } \\
\text { Deviation }\end{array}$ & $\begin{array}{c}\text { Verbal } \\
\text { Interpretation }\end{array}$ \\
\hline $\begin{array}{l}\text { 1. When I don't understand something I keep asking } \\
\text { questions. }\end{array}$ & 4.25 & 0.78 & High \\
\hline $\begin{array}{l}\text { 2. Learning good study skills can improve my math } \\
\text { ability. }\end{array}$ & 4.41 & 0.75 & High \\
\hline 3. Even if I work hard, I'll never really learn math. & 1.52 & 0.71 & High \\
\hline $\begin{array}{l}\text { 4. If math were easy for me, then I wouldn't have to } \\
\text { spend so much time on homework. }\end{array}$ & 2.32 & 1.12 & Moderately high \\
\hline $\begin{array}{l}\text { 5. It is frustrating when I have to work hard to } \\
\text { understand a problem. }\end{array}$ & 2.41 & 1.23 & Moderately high \\
\hline $\begin{array}{l}\text { 6. I can learn new things, but I can't really change the } \\
\text { math ability I was born with. }\end{array}$ & 2.84 & 1.01 & Moderately high \\
\hline 7. I'm just not a math person. & 2.36 & 1.22 & Low \\
\hline $\begin{array}{l}\text { 8. I prefer mathematics when I have to work hard to } \\
\text { find a solution. }\end{array}$ & 4.21 & 0.85 & High \\
\hline $\begin{array}{l}\text { 9. I find I cannot do hard mathematics problems even } \\
\text { with patience. }\end{array}$ & 1.62 & 0.95 & High \\
\hline $\begin{array}{l}\text { 10. I am certain I can learn how to solve the most } \\
\text { difficult mathematics problem. }\end{array}$ & 4.10 & 1.03 & High \\
\hline Overall & 3.01 & 1.15 & Moderately high \\
\hline
\end{tabular}

Table 16:

Student's Epistemological Beliefs on Control of Knowledge Acquisition - General

\begin{tabular}{|c|c|c|c|}
\hline Indicators & Mean & $\begin{array}{l}\text { Standard } \\
\text { Deviation }\end{array}$ & $\begin{array}{c}\text { Verbal } \\
\text { Interpretation }\end{array}$ \\
\hline $\begin{array}{l}\text { 1. Better study habits are the key to success for persons } \\
\text { who struggle in math. }\end{array}$ & 4.48 & 0.98 & High \\
\hline $\begin{array}{l}\text { 2. Someone who doesn't have high natural ability is still } \\
\text { capable of learning difficult material. }\end{array}$ & 4.25 & 0.88 & High \\
\hline $\begin{array}{l}\text { 3. When you don't understand something you should keep } \\
\text { asking questions. }\end{array}$ & 4.23 & 0.78 & High \\
\hline $\begin{array}{l}\text { 4. Learning good study skills can improve a person's math } \\
\text { ability. }\end{array}$ & 4.25 & 1.02 & High \\
\hline $\begin{array}{l}\text { 5. Some people are born with great math ability and some } \\
\text { aren't. }\end{array}$ & 3.85 & 1.12 & High \\
\hline 6. Math ability is really just something you're born with. & 2.85 & 0.85 & Moderately high \\
\hline $\begin{array}{l}\text { 7. The smartest math students don't have to do many } \\
\text { problems because they just get it. }\end{array}$ & 2.32 & 0.98 & Moderately high \\
\hline $\begin{array}{l}\text { 8. It is frustrating for students to have to work hard to } \\
\text { understand a problem. }\end{array}$ & 2.78 & 0.92 & Moderately high \\
\hline $\begin{array}{l}\text { 9. You can learn new things, and you can change the math } \\
\text { ability you were born with }\end{array}$ & 3.21 & 0.85 & Moderately high \\
\hline \multirow[t]{2}{*}{$\begin{array}{l}\text { 10. Most people know at an early age whether they are good } \\
\text { at math or not. }\end{array}$} & 3.12 & 1.01 & Moderately high \\
\hline & 3.50 & 1.06 & Moderately High \\
\hline
\end{tabular}


Table 17:

Student's Epistemological Beliefs on Speed of Knowledge Acquisition

\begin{tabular}{lccc}
\hline \multicolumn{1}{c}{ Indicators } & Mean & $\begin{array}{c}\text { Standard } \\
\text { Deviation }\end{array}$ & $\begin{array}{c}\text { Verbal } \\
\text { Interpretation }\end{array}$ \\
\hline $\begin{array}{l}\text { 1. When it comes to math, most students either get it } \\
\text { quickly or not at all. }\end{array}$ & 3.85 & 0.84 & High \\
$\begin{array}{l}\text { 2. It takes a lot of time to learn math. } \\
\text { 3. If I can't solve a problem quickly I get frustrated and } \\
\text { tend to give up. }\end{array}$ & 3.32 & 1.02 & High \\
4. When I encounter a difficult math problem, I stick with & 4.09 & 1.25 & High \\
$\begin{array}{l}\text { it until I solve it. } \\
\text { 5. With enough time, almost everyone can learn algebra if } \\
\text { they really try. }\end{array}$ & 4.41 & 0.98 & High \\
$\begin{array}{l}\text { 6. If I don't understand something presented in class, } \\
\text { going back over it later is going to help. }\end{array}$ & 3.52 & 1.21 & High \\
$\begin{array}{l}\text { 7. If you can't solve a problem in a few minutes you're not } \\
\text { going to solve it without help. }\end{array}$ & 2.41 & 1.05 & Low \\
$\begin{array}{l}\text { 8. If you know what you're doing, you shouldn't have to } \\
\text { spend more than a few minutes to complete a homework } \\
\text { problem. }\end{array}$ & 3.21 & 1.24 & Moderately high \\
$\begin{array}{l}\text { 9. It is frustrating to read a problem and not know } \\
\text { immediately how to begin to solve it. }\end{array}$ & 2.98 & 1.08 & Moderately high \\
$\begin{array}{l}\text { 10. I can do better in mathematics if I am given more time } \\
\text { to learn the concepts. }\end{array}$ & 4.25 & 1.04 & High \\
\hline$\quad$ Overall & $\mathbf{3 . 4 2}$ & $\mathbf{1 . 2 9}$ & Moderately high \\
\hline
\end{tabular}

Table 18:

Correlation of Mathematical Curiosity and Epistemological Beliefs to Mathematics Performance

\begin{tabular}{lccc}
\hline \multicolumn{1}{c}{ Pair of Variables } & Correlation Coefficient & p-value & Interpretation \\
\hline $\begin{array}{l}\text { Mathematical Curiosity and Mathematics } \\
\text { Performance. }\end{array}$ & 0.85 & 0.000 & Significant \\
$\begin{array}{l}\text { Epistemological Beliefs and Mathematics } \\
\text { Performance. }\end{array}$ & 0.76 & 0.000 & Significant \\
\hline
\end{tabular}

It is also evident from the table 18 that both mathematical curiosity and epistemological beliefs are significantly correlated to mathematics epistemological beliefs are factors that could affect students' performance in mathematics. Moreover, the positive correlation coefficients indicate that high level of mathematical curiosity and epistemological beliefs are associated to high performance in mathematics.

Table 19 shows the multiple regression analysis for predicting mathematics performance in terms of mathematical curiosity and epistemological beliefs.

It can be also viewed from the table 19 that both mathematical curiosity and epistemological beliefs significantly influence mathematics performance. Moreover, $\mathrm{R}^{2}$ shows that $42 \%$ of the variation in mathematics performance can be explained by mathematical curiosity and epistemological beliefs. This implies that mathematical curiosity and epistemological beliefs are influencing factors to mathematics performance.

The following are the findings of the study. The level of mathematical curiosity of pre-service teachers is high on four dimensions, namely: exploration, absorption, epistemic curiosity, and perceptual curiosity.

The level of epistemological beliefs of preservice teachers is high on three dimensions, 
Table 19:

Multiple Regression Analysis for Predicting Mathematics Performance

\begin{tabular}{|c|c|c|c|c|c|}
\hline \multicolumn{6}{|l|}{ Model Summary } \\
\hline $\mathbf{R}$ & $\mathbf{R}^{2}$ & Adjusted $\mathbf{R}^{2}$ & \multicolumn{3}{|c|}{ Std Error of Estimate } \\
\hline 0.65 & 0.42 & 0.41 & \multicolumn{2}{|l|}{0.228} & \\
\hline \multicolumn{6}{|l|}{ ANOVA } \\
\hline & Sum of Squares & df & Mean Square & $\mathbf{F}$ & p-value \\
\hline Regression & 15.23 & 2 & 7.62 & 47.63 & 0.000 \\
\hline Residual & 11.32 & 164 & 0.16 & & \\
\hline Total & 26.55 & 166 & & & \\
\hline \multicolumn{6}{|l|}{ Coefficients } \\
\hline Predictor & Unstandardized Beta & Std Error & Standardized Beta & $\mathbf{t}$ & p-value \\
\hline Mathematical Curiosity & 0.49 & 0.078 & 0.56 & 5.85 & 0.000 \\
\hline Epistemological Beliefs & 0.39 & 0.054 & 0.42 & 3.25 & 0.000 \\
\hline
\end{tabular}

namely: certainty of knowledge, structure of knowledge, and source of knowledge. On the other hand, it is moderately high on the other three dimensions, namely: control of knowledge acquisition (personal), control of knowledge acquisition (general), and speed of knowledge acquisition.

Mathematical curiosity and epistemological beliefs are significantly correlated to mathematics performance. Mathematical curiosity and epistemological beliefs significantly influence mathematics performance.

\section{CONCLUSION}

Based on the findings of this study, the following conclusions are made. Students with high level of mathematical curiosity tend to have higher mathematics performance. Students with high level of epistemological beliefs tend to have higher mathematics performance.

Based on the findings and conclusions of this study, the following are hereby recommended. Firstly, a profiling of the mathematical curiosity and epistemological beliefs of pre-service teachers should be done across personological variables (gender, choice of majorship, high school graduated, etc.) should be done.

Lastly, secondly, a study that determines which dimensions of mathematical curiosity and epistemological beliefs influence mathematics performance of pre-service teachers could be conducted. ${ }^{1}$

\section{References}

Berlyne, D.E. (1960a). “A Theory of Human Curiosity” in British Journal of Psychology, Vol.1(1).

Berlyne, D.E. (1960b). Conflict, Arousal, and Curiosity. New York: McGraw-Hill.

Berlyne, D.E. (1966). “Curiosity and Exploration” in Science, 153, pp.25-33.

Best, J.W. \& J. Kahn. (1989). Research in Education. Englewood: Prentice-Hall International Inc., $2^{\text {nd }}$ edition.

Bonjour, L. (2002). Epistemology: Classic Problems and Contemporary Solutions. Lanham, Maryland: Rowman \& Littlefield.

Collins, R.P., J.A. Litman \& C.D. Spielberger. (2004). "The Measurement of Perceptual Curiosity" in Personality and Individual Differences, 36, pp.1127-1141.

Cooper, S.E. \& D.A.G. Robinson. (1991). “The Relationship of Mathematics Self-Efficacy Beliefs to Mathematics Anxiety and Performances” in Measurement and Evaluation in Counseling and Development, 24(1), pp.4-11.

De Corte, J. (2008). “Unraveling the Relationship

\footnotetext{
${ }^{1}$ Statement: We, hereby, declared that this paper is our original work and not product of plagiarism in any books or journal that have been published. The citation is stated and it is available showed in the References. This paper is never also being submitted and published by other scholarly journal.
} 
between Students’ Mathematics-Related Beliefs and the Classroom Culture" in European Psychologist, Vol.13.

Hackett, G. \& N.E. Betz. (1989). “An Exploration of the Mathematics Self-Efficacy/Mathematics Performance Correspondence" in Journal for Research in Mathematics Education, 20, pp.261-273.

Hyde, J.S., E. Fennema \& S.J. Lamon. (1990). "Gender Differences in Mathematical Performance: A Meta-Analysis” in Psychological Bulletin, 107, pp.139-155.

Isiksal, Mine. (2005). "Pre-service Teachers' Performance in their University Coursework and Mathematical Self-Efficacy Beliefs: What is the Role of Gender and Year in Program?” in The Mathematics Educator, Vol.15, No.2, pp.8-16.

Kardash, C.M. \& R.J. Scholes. (1996). "Effects of Pre-existing Beliefs, Epistemological Beliefs, and Need for Cognition on Interpretation of Controversial Issues” in Journal of Educational Psychology, 88, pp.260-271.

Kashdan, T.B. (2004). "Curiosity” in C. Peterson \& M.E.P. Seligman [eds]. Character Strengths and Virtues: A Handbook and Classification. Washington, DC: American Psychological Association, pp.125-141.

Kashdan, T.B. \& P.J. Silvia. (2009). "Curiosity and Interest: The Benefits of Thriving on Novelty and Challenge” in C.R. Snyder \& S.J. Lopez [eds]. Handbook of Positive Psychology, Volume 2. New York: Oxford University Press, pp.367-374.

Keller, J.M. (1999). "Motivational Systems” in H.D. Stolovitch \& E.J. Keeps [eds]. Handbook of Human Performance Technology. San Francisco: Jossey-Bass Inc., Publisher, $2^{\text {nd }}$ edition.

Litman, J.A. (2000). “Construct and Predictive Validity of Measures of Epistemic and Perceptual
Curiosity”. Unpublished Doctoral Dissertation, Tampa, USA [United States of America]: University of South Florida.

Litman, J.A. \& C.D. Spielberger. (2003). “The Measurement of Epistemic Curiosity and its Diversive and Specific Components" in Journal of Personality Assessment, 80, pp.75-86.

Loewenstein, G. (1994). "The Psychology of Curiosity: A Review and Reinterpretation” in Psychological Bulletin, 116, pp.75-98.

Maw, W.H. \& E.W. Maw. (1972). "Differences between High- and Low-Curiosity FifthGrade Children in Their Recognition of Verbal Absurdities” in Journal of Educational Psychology, 63, pp.558-562.

Renner, B. (2006). “Curiosity about People: The Development of a Social Curiosity Measure in Adults” in Journal of Personality Assessment, 87, pp.305-316.

Sandoval, W.A. \& K. Morrison. (2003). "High School Students' Ideas about Theories and Theory Change After a Biological Inquiry Unit” in Journal of Research in Science Teaching, 40, pp.369-392.

Schommer, M. (1990). "Effects of Beliefs about the Nature of Knowledge on Comprehension” in Journal of Educational Psychology, 82, pp.498-504.

Unal, H. (2005). "The Influence of Curiosity and Spatial Ability on Preservice Middle and Secondary Mathematics Teachers’ Understanding of Geometry”. Unpublished Doctoral Dissertion. Florida, USA [United States of America]: College of Education, the Florida State University.

Windschitl, M. \& T. Andre. (1998). “Using Computer Simulations to Enhance Conceptual Change: The Roles of Constructivist Instruction and Student Epistemological Beliefs” in Journal of Research in Science Teaching, 35(2), pp.145-160. 